\title{
Favorable Bioactivity of the SDHI Fungicide Benzovindiflupyr Against Sclerotinia sclerotiorum Mycelial Growth, Sclerotial Production, and Myceliogenic and Carpogenic Germination of Sclerotia
}

\author{
Xue-ping Huang, ${ }^{1,3}$ Jian Luo, ${ }^{2,3}$ Yu-fei Song, ${ }^{1,3}$ Bei-xing Li, ${ }^{2,3}$ Wei Mu, ${ }^{2,3}$ and Feng Liu ${ }^{1,3+}$ \\ ${ }^{1}$ Shandong Provincial Key Laboratory for Biology of Vegetable Diseases and Insect Pests, College of Plant Protection, Shandong \\ Agricultural University, Tai' an, Shandong 271018, P. R. China; ${ }^{2}$ Research Center of Pesticide Environmental Toxicology, Shan- \\ dong Agricultural University, Tai'an, Shandong 271018, China; and ${ }^{3}$ Key Laboratory of Pesticide Toxicology \& Application \\ Technique, Shandong Agricultural University, Tai'an, Shandong 271018, P. R. China
}

\begin{abstract}
Sclerotinia sclerotiorum, which can cause Sclerotinia stem rot, is a prevalent plant pathogen. This study aims to evaluate the application potential of benzovindiflupyr, a new generation of succinate dehydrogenase inhibitor (SDHI), against S. sclerotiorum. In our study, 181 isolates collected from different crops (including eggplant [ $n=34]$, cucumber [ $n=27]$, tomato $[n=29]$, pepper $[n=35]$, pumpkin $[n=32]$, and kidney bean $[n=$ 25]) in China were used to establish baseline sensitivity to benzovindiflupyr. The frequency distribution of the $50 \%$ effective concentration $\left(\mathrm{EC}_{50}\right)$ values of benzovindiflupyr was a unimodal curve, with mean $\mathrm{EC}_{50}$ values of $0.0260 \pm 0.011 \mu \mathrm{g} / \mathrm{ml}$, and no significant differences in

S. sclerotiorum. In addition, benzovindiflupyr showed good systemic translocation in eggplant. Using benzovindiflupyr at $100 \mu \mathrm{g} / \mathrm{ml}$ yielded efficacies of 71.3 and $80.5 \%$ for transverse activity and cross-layer activity, respectively, which were higher than those of acropetal and basipetal treatments (43.6 and $44.7 \%$, respectively). Greenhouse experiments were then carried out at two experimental sites for verification. Applying benzovindiflupyr at $200 \mathrm{~g}$ a.i. $\mathrm{ha}^{-1}$ significantly reduced the disease incidence and severity of Sclerotinia stem rot. Overall, the results demonstrated that benzovindiflupyr is a potential alternative product to control Sclerotinia stem rot.
\end{abstract} mean $\mathrm{EC}_{50}$ existed among the various crops $(P>0.99)$. Benzovindiflupyr can effectively inhibit mycelial growth, sclerotial production, sclerotial shape, and myceliogenic and carpogenic germination of the sclerotia of
Keywords: baseline, benzovindiflupyr, sclerotia, Sclerotinia sclerotiorum, succinate dehydrogenase inhibitor, translocation.
Sclerotinia sclerotiorum (Lib.) de Bary is a necrotrophic plant pathogen known for its wide host range and worldwide distribution; it can infect at least 408 species of plants worldwide, including rapeseed, peanut, sunflower, soybean, and tomato (Boland and Hall 1994; Bolton et al. 2006; Purdy 1979; Tores and Moreno 1987). This pathogen is the causative agent of Sclerotinia stem rot, which can reduce yields by 10 to $80 \%$ in oilseed rape in China and cause yield losses of $44 \%$ in commercial dry bean in North Dakota (McCreary et al. 2016; Wang et al. 2014). In the United States, Sclerotinia stem rot ranks in the top 10 yield-reducing diseases of soybean, and this disease led to serious yield losses from 2010 to 2014 (Allen et al. 2017; Koenning and Wrather 2010).

The application of fungicides is still the mainstay tactic for controlling Sclerotinia stem rot on crops and vegetables such as oilseed rape, peanut, sunflower, and soybean (Steadman 1979; Wang et al. 2014). Nevertheless, frequent and intensive use of fungicides such as benzimidazole (carbendazim) and dicarboximide (dimethachlon) has been a leading cause of the emergence and prevalence of resistance and a decrease in efficacy against $S$. sclerotiorum (Zhou et al. 2014; Zhu et al. 2016). Consequently, it is necessary to quickly identify appropriate substitute fungicides with new modes of action and to formulate a more effective and sustainable fungicide application strategy for managing $S$. sclerotiorum.

${ }^{\dagger}$ Corresponding author: F. Liu; E-mail: fliu@sdau.edu.cn

Funding: This work was supported by grants from the National Key R\&D Program of China (2017YFD0200307) and the National Natural Science Foundation of China (31772203).

The author(s) declare no conflict of interest.

Accepted for publication 24 January 2019.

(c) 2019 The American Phytopathological Society
As a second-generation benzonorbornene succinate dehydrogenase inhibitor (SDHI) carboxamide developed and commercialized by Syngenta Crop Protection (Ishii et al. 2016; Villani et al. 2016), benzovindiflupyr (Solatenol) offers favorable performance in the control of various diseases because it can bind to the waxy layer of crop leaves and be gradually absorbed into the leaf tissue to provide long-lasting disease control (European Food Safety Authority 2015; Jeanmart et al. 2016). Through laboratory tests, we preliminarily found that benzovindiflupyr has high inhibitory activity against the mycelial growth of $S$. sclerotiorum. Considering the characteristics of the fungicide, we conducted a detailed and comprehensive study to evaluate the application potential of this fungicide against S. sclerotiorum.

This study intended to (i) establish the baseline sensitivity of S. sclerotiorum to benzovindiflupyr on various crops in China, (ii) determine the inhibitory activity of benzovindiflupyr on different growth stages of $S$. sclerotiorum, (iii) evaluate the systemic translocation of benzovindiflupyr for suppressing $S$. sclerotiorum, and (iv) test the efficacy of benzovindiflupyr in the control of Sclerotinia stem rot in the greenhouse.

\section{Materials and Methods}

Fungicide, media, and isolates of $\boldsymbol{S}$. sclerotiorum. Technicalgrade benzovindiflupyr (97\% active ingredient [a.i.]; Syngenta Investment Co., Ltd.) and dimethachlon (96\% a.i.; Jiangxi Heyi Chemical Co., Ltd.) were dissolved in acetone to produce stock solutions of $10,000 \mu \mathrm{g} / \mathrm{ml}$. Benzovindiflupyr (emulsifiable concentrate [EC] at $100 \mathrm{~g} \mathrm{liter}^{-1}$ ) was purchased from Syngenta Crop Protection Ltd. Carbendazim (50\% wettable powder [WP]) was purchased from Zhejiang Xinan Chemical Industrial Group Co., Ltd. Dimethachlon (40\% WP) was purchased from Qingdao Audis Bio. Tech. Co., Ltd.

Potato dextrose agar (PDA) was prepared by placing the following ingredients into 1 liter of distilled water: $200 \mathrm{~g}$ of potato, $20 \mathrm{~g}$ of dextrose, and $20 \mathrm{~g}$ of agar (Griffith et al. 2007).

Isolates $(n=181)$ of $S$. sclerotiorum were collected from eggplant, cucumber, tomato, pepper, pumpkin, and kidney bean in Changle, 
Shouguang, Linqu, Qingzhou and Tai' an in China in 2015 and 2016, where benzovindiflupyr had never been used. In each region, mature sclerotia were sampled from six fields separated from one another by more than $20 \mathrm{~km}$ and never exposed to any SDHI fungicides. In each field, several plants with typical symptoms of Sclerotinia stem rot were arbitrarily collected. Sclerotia were cultured on PDA media and stored at $4^{\circ} \mathrm{C}$ in a refrigerator.

Baseline sensitivity to benzovindiflupyr. The sensitivity to benzovindiflupyr was determined according to the method reported by Liang et al. (2015). Briefly, a stock solution of benzovindiflupyr was diluted with sterile deionized water containing $0.1 \%$ Tween 80. PDA medium was routinely supplemented with benzovindiflupyr to yield final concentrations of $0,0.0125,0.025,0.05,0.1,0.2,0.4$, and $0.8 \mu \mathrm{g} / \mathrm{ml}$. Mycelial plugs ( $7 \mathrm{~mm}$ in diameter) were removed from the edge of 2-day-old colonies of each isolate and placed upside down onto 9-cm Petri plates containing PDA. Petri plates with PDA amended with $0.008 \%$ acetone and $0.01 \%$ Tween 80 were used as a solvent control. Petri plates with nontreated PDA were used as blank controls. Each isolate was incubated at $25^{\circ} \mathrm{C}$ for $48 \mathrm{~h}$ with three replicates. The diameter of each colony was measured twice at perpendicular angles and used to calculate the percentage of growth inhibition. The $50 \%$ effective concentration $\left(\mathrm{EC}_{50}\right)$ values of benzovindiflupyr for each isolate were calculated by regressing growth inhibition against the log-transformed fungicide concentration (Thomulka et al. 1996). The experiment was performed twice.

Bioactivity of benzovindiflupyr on sclerotial production of S. sclerotiorum. The bioactivity of benzovindiflupyr on sclerotial production was tested using three $S$. sclerotiorum isolates (SZ12, QZ5, and LQ3). For each isolate, mycelial plugs were cut from the edge of 2-day-old colonies and transferred to the center of Petri plates with PDA supplemented with benzovindiflupyr at final concentrations of $0.2,0.4$, and $0.8 \mu \mathrm{g} / \mathrm{ml}$. Petri plates with PDA supplemented with $0.008 \%$ acetone and $0.01 \%$ Tween 80 were used as solvent controls. Petri plates with nontreated PDA were used as blank controls. Eight Petri plates for each isolate were incubated at $24^{\circ} \mathrm{C}$ in the dark for 21 days. The number and dry weight of the sclerotia on each plate were then determined ( $\mathrm{Lu}$ et al. 2015). The experiment was performed twice.

Bioactivity of benzovindiflupyr on myceliogenic germination of sclerotia. The bioactivity of benzovindiflupyr on the myceliogenic germination of $S$. sclerotiorum was determined according to the methods reported by $\mathrm{Xu}$ et al. (2015). The sclerotia were harvested from Petri plates in which isolates (SZ12 and QZ5) were incubated at $20^{\circ} \mathrm{C}$ in the dark for 15 days. Sclerotia that were 3 to $5 \mathrm{~mm}$ in diameter were surface disinfested with $95 \%$ alcohol for 3 min, washed three times with sterile distilled water, and dried with sterilized filter paper. The sclerotia were placed on Petri plates containing PDA amended with benzovindiflupyr or dimethachlon (used as a reference fungicide) at $0.5,1,2,4$, and $8 \mu \mathrm{g} / \mathrm{ml}$. Petri plates with PDA supplemented with $0.08 \%$ acetone and $0.01 \%$ Tween 80 were used as solvent controls. Petri plates with nonamended PDA were used as blank controls. A replicate consisted of six Petri plates per treatment, where five sclerotia were inset in each plate, and three replicates were performed per experiment. The experiment was performed twice. After incubation at $25^{\circ} \mathrm{C}$ in the dark for 3,4 , and 5 days, myceliogenic germination of the sclerotia was examined under a light microscope. The evaluation standard of sclerotial germination was the presence of mycelia $\geq 2 \mathrm{~mm}$ long. The percent inhibition of sclerotial germination was calculated by the following equation: inhibition of sclerotial germination $(\%)=[$ (the number of germinated sclerotia in the control - the number of germinated sclerotia in the treatment)/the number of germinated sclerotia in the control] $\times 100(\mathrm{Xu}$ et al. 2015).

Bioactivity of benzovindiflupyr on carpogenic germination of sclerotia. As mentioned above, similarly sized sclerotia (3 to $5 \mathrm{~mm}$ in diameter) of two isolates of S. sclerotiorum (SZ12 and QZ5) produced on PDA plates were harvested, air dried, and stored at $4{ }^{\circ} \mathrm{C}$ for 60 days. As described by Wu and Subbarao (2008), 30 sclerotia were located on a polyurethane foam block that was placed in a styrofoam cup pierced with five holes $(2 \mathrm{~mm}$ in diameter by $1 \mathrm{~cm}$ in height). The stock solutions of benzovindiflupyr and dimethachlon were diluted with sterile deionized water containing $0.1 \%$ Tween 80 to 2,5 , and $10 \mu \mathrm{g} / \mathrm{ml}$. There were two sets of controls, including sterile deionized water with $0.1 \%$ acetone and $0.1 \%$ Tween 80 (as a solvent control) and sterile deionized water (as a blank control). The sclerotia in each cup were sprayed with $10 \mathrm{ml}$ of diluent using sterile medical syringes twice a week. A replicate consisted of four cups per treatment, in which 30 sclerotia were located in each cup and three replicates were performed per experiment. Then, all cups were covered with 90-mm Petri dishes and placed in an incubator at $18^{\circ} \mathrm{C}$ with a 12-h photoperiod. It has been reported that, if sclerotia are incubated for 60 days at $4^{\circ} \mathrm{C}$, the time to germination at $18^{\circ} \mathrm{C}$ is 40 to 50 days (Clarkson et al. 2007). After incubation for 30, 40, and 50 days, carpogenic germination of sclerotia that produced visible stipes or apothecia was recorded. The inhibition of carpogenic germination of the sclerotia was calculated as previously described (Ojaghian et al. 2014). The experiment was performed twice.

Systemic translocation of benzovindiflupyr in eggplant. The systemic translocation of benzovindiflupyr in eggplant was determined using previously described methods (Ren et al. 2011), with slight modifications. After disinfestation in water at $40^{\circ} \mathrm{C}$ for $6 \mathrm{~h}$, eggplant seed were grown in pots $(20 \mathrm{~cm}$ in diameter by $14 \mathrm{~cm}$ in height) containing autoclaved sandy loam and organic matter (3:1) at $25^{\circ} \mathrm{C}$ with a 12 -h photoperiod and $80 \%$ relative humidity. After 7 weeks of cultivation, the third fully expanded leaf at the five- or six-leaf stage (Fig. 1A and B) was sprayed with fungicides, regardless of which activity was evaluated. At $24 \mathrm{~h}$ after fungicide application, mycelial plugs ( $5 \mathrm{~mm}$ in diameter) of $S$. sclerotiorum isolates were transferred onto the left surface of each leaf. Benzovindiflupyr or dimethachlon (as a reference fungicide) at $100 \mu \mathrm{g} / \mathrm{ml}$ was applied on (i) the right-half upper surface of the third leaf to evaluate the transverse activity by assessing the lesion diameter on the left-half upper surface of the third leaf (Fig. 1C), (ii) the lower surface of the third leaf to determine the cross-layer activity by assessing the lesion diameter on the upper surface of the third leaf (Fig. 1D), (iii) the upper surface of the third leaf to estimate the acropetal activity by assessing the lesion size on the upper surface of the second leaf, or (iv) the upper surface of the third leaf to estimate the basipetal activity by assessing the lesion size on the upper surface of the fourth leaf. The spray volume was $4 \mathrm{ml} / \mathrm{leaf}$. Nontreated control leaves were sprayed with water. To avoid cross-contamination, pots with plants treated as described above were placed in a randomized complete block design and spaced $30 \mathrm{~cm}$ apart. Twenty replicates (plants) for each treatment were included, and the experiment was performed twice. The lesion area was determined by measuring the diameters in two perpendicular directions 3 days after incubation. The control efficacy was calculated as follows: disease control efficacy $(\%)=$ [(average lesion diameter in the water control - average lesion diameter in the treatment)/lesion diameter in the water control] $\times 100$.

Greenhouse trials. In 2017, greenhouse experiments were performed in two eggplant greenhouses. The trial sites were located in Changle $\left(118^{\circ} 48^{\prime} \mathrm{E}, 36^{\circ} 37^{\prime} \mathrm{N}\right)$ and Tai' an $\left(117^{\circ} 13^{\prime} \mathrm{E}, 36^{\circ} 18^{\prime} \mathrm{N}\right)$, Shandong, China. Eggplant seedlings of variety Heixuanfeng were transplanted to the greenhouse on 5 July and 25 June. The initial fungicide application was performed when most of the eggplants were flowering. The six treatments were (i) a water control, (ii) benzovindiflupyr (100 $\mathrm{g} \mathrm{liter}^{-1} \mathrm{EC}$ ) at $100 \mathrm{~g}$ a.i. ha ${ }^{-1}$, (iii) benzovindiflupyr (100 $\left.\mathrm{g} \mathrm{liter}^{-1} \mathrm{EC}\right)$ at $150 \mathrm{~g}$ a.i. ha $\mathrm{g}^{-1}$, (iv) benzovindiflupyr (100 g liter $^{-1}$ EC) at $200 \mathrm{~g}$ a.i. ha ${ }^{-1}$, (v) dimethachlon (40\% WP) at $600 \mathrm{~g}$ a.i. $\mathrm{ha}^{-1}$, and (vi) carbendazim (50\% WP) at $1,125 \mathrm{~g}$ a.i. ha $\mathrm{ha}^{-1}$. All treatments had four replications, and plots were arranged in a randomized complete block design; each plot was 8 by $4 \mathrm{~m}$, with approximately 240 plants/plot. Fungicides were sprayed twice at 7-day intervals. All treatments were applied by the universal MATABI-16 knapsack hand sprayer (pressure: $0.3 \mathrm{MPa}$, cone nozzle, flow rate $=$ $650 \mathrm{ml} \mathrm{min}^{-1}$ ) with a spray volume of 675 liters ha ${ }^{-1}$. In each plot, 130 randomly selected eggplants were investigated to estimate the efficacy of the fungicide. Disease assessments were made 14 days after the last application using a 0-to-9 rating scale. Disease severity was assessed using the following scale: $0=$ no lesions, $1=$ lesions on $<5 \%$ of the 
stem, $3=$ lesions on 6 to $15 \%$ of the stem, $5=$ lesions on 16 to $30 \%$ of the stem, $7=$ lesions on 31 to $50 \%$ of the stem, and $9=$ lesions on $>50 \%$ of the stem (Yang et al. 2009).

Statistical analysis. For the bioassay, one-way analysis of variance was conducted using the generalized linear model (GLM) in SPSS 14.0 (Statistical Package for Social Science; SPSS Inc.) to assess the effects of fungicide programs on mycelial growth, sclerotial production, inhibition of sclerotial germination, and control efficacy. Before analysis, the normality of the residuals and homogeneity of the data variance were examined using the Shapiro-Wilk test and Levene's test, respectively. Because there were no significant differences between the two repeated trials for each bioassay test, the data from the two experimental runs were combined into a single data set for statistical analysis. For all experiments, Bonferroni correction $(\alpha=0.05)$ was conducted to assess the significant differences among the means according to the GLM procedure of SPSS.

The experiment to determine the effects of fungicides on mycelial growth and sclerotial production was performed using a completely randomized design. In the mycelial growth test, the $\mathrm{EC}_{50}$ values of benzovindiflupyr against $S$. sclerotiorum isolates were calculated by performing a regression of inhibition percent against $\log _{10}$ fungicide concentration with a probit analysis in SPSS. The average $\mathrm{EC}_{50}$ values of the isolates collected from different crops were compared using the GLM with Bonferroni correction. For the sclerotial production assay, the number of sclerotia per dish was transformed using square-root transformation to satisfy the assumption of normal distribution. The analyses were performed separately for each isolate because the three isolates were tested individually.

The experiments to determine the effect of fungicides in inhibiting sclerotial germination and to evaluate the systemic translocation of fungicides were arranged in randomized block designs in which replications were used as blocks. For the inhibition of sclerotial germination, the analyses were performed separately for each isolate and each assessment time. In addition, data expressed as percentages, such as the inhibition of sclerotial germination, control efficacy, and disease incidence, were arcsine transformed before analysis to meet the assumptions of the models. The mean values of the transformed data were compared using the GLM with Bonferroni correction $(\alpha=0.05)$ because the variances of the experimental errors were homogeneous.

The ordinal data from the greenhouse trials were analyzed by nonparametric methods using SAS 9.2 (SAS Institute Inc.) to estimate the disease severity. The rank of an observation represents the order of values, which was determined by the PROC RANK and PROC MIXED in SAS. The mean rank $\left(\bar{R}_{i}\right.$.) indicates the average order of all of the replications for the $i$ th treatment. The relative treatment effect $\left(\hat{p}_{i}\right)$ can be calculated using $\hat{p}_{i}=1 / N\left(\bar{R}_{i} \cdot-1 / 2\right)$, in which $N$ is the number of observations. Additionally, the $\hat{p}_{i}$ values and their $95 \%$ confidence intervals $(95 \% \mathrm{CI})$ were analyzed using the 'LD_CI' SAS macro. Differences in the $\hat{p}_{i}$ values are used to compare the disease severity among treatments. A larger value of $\hat{p}_{i}$ indicates a higher value of disease severity. The $\hat{p}_{i}$ values between the two treatments are significantly different from each other when the $95 \%$ CIs of each $\hat{p}_{i}$ do not overlap (Shah and Madden 2004).

\section{Results}

Baseline sensitivity to benzovindiflupyr. In this study, the mycelial growth inhibition test was used to assess the sensitivity of 181 $S$. sclerotiorum isolates collected from six crops to the SDHI fungicide benzovindiflupyr. The results showed that the mean $\mathrm{EC}_{50}$ values for S. sclerotiorum collected from different crops (including eggplant $[n=34]$, cucumber $[n=27]$, tomato $[n=29]$, pepper [ $n=35]$,

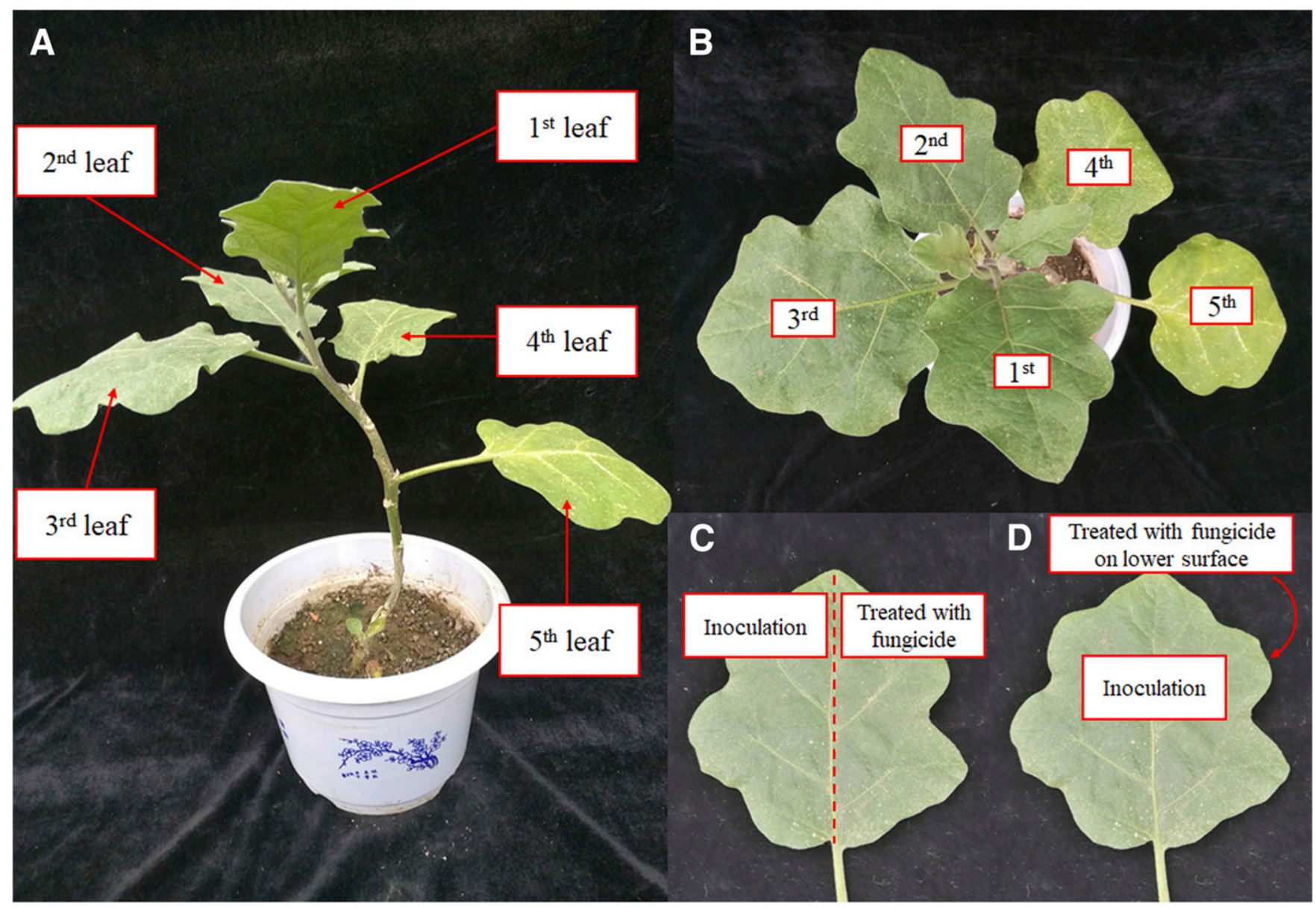

Fig. 1. Potted eggplants (Heixuanfeng) at the five-leaf stage when viewed from A, the front and B, the top. C, Evaluation of transverse activity bioassay on the third leaf and D, crosslayer activity bioassay. 
pumpkin $[n=32]$, and kidney bean $[n=25]$ ) were very similar (between 0.0241 and $0.0399 ; P>0.99$ ) (Table 1 ). There were no significant differences in the mean $\mathrm{EC}_{50}$ values among each crop. This result suggested that those $181 \mathrm{~S}$. sclerotiorum isolates could be used to establish baseline sensitivity to benzovindiflupyr.

The frequency distribution of individual benzovindiflupyr $\mathrm{EC}_{50}$ values for 181 field isolates from different crops was a unimodal curve over a narrow range (Fig. 2), and the range of values (the highest $\mathrm{EC}_{50}$ value/the lowest $\mathrm{EC}_{50}$ value) was 21.6. The $\mathrm{EC}_{50}$ values for benzovindiflupyr in inhibiting mycelial growth of $S$. sclerotiorum varied from 0.0033 to $0.0713 \mu \mathrm{g} / \mathrm{ml}$, with a mean value of $0.0260 \pm$ $0.011 \mu \mathrm{g} / \mathrm{ml}$. The results indicated that benzovindiflupyr effectively inhibited the mycelial growth of $S$. sclerotiorum.

Bioactivity of benzovindiflupyr against sclerotial production of $S$. sclerotiorum. The sclerotia of the three $S$. sclerotiorum isolates had different phenotypes on PDA regardless of whether it was amended with benzovindiflupyr (Fig. 3A). The morphology of the sclerotia was changed by treatment (Fig. 4B), with some larger or smaller sclerotia appearing on PDA amended with benzovindiflupyr compared with those on the nontreated control. The dry weight of the sclerotia decreased with the concentration of benzovindiflupyr (Fig. 3C). The number of sclerotia also significantly decreased after treatment with benzovindiflupyr $(P<0.0019)$ (Fig. 3D).

Bioactivity of benzovindiflupyr on myceliogenic germination of sclerotia. The inhibition of myceliogenic germination of the isolates (SZ12 and QZ5) by benzovindiflupyr and dimethachlon also increased clearly with fungicide concentration. Sclerotia can gradually generate mycelium; thus, the inhibition of myceliogenic germination eased over time. At the highest tested concentration of benzovindiflupyr $(8 \mu \mathrm{g} / \mathrm{ml})$, myceliogenic germination of the two isolates was completely inhibited (Table 2). Notably, benzovindiflupyr showed similar bioactivity to dimethachlon in inhibiting the myceliogenic germination of sclerotia.

Bioactivity of benzovindiflupyr on carpogenic germination of sclerotia. For isolates SZ12 and QZ5, all sclerotia used in the control germinated carpogenically, producing visible stipes. The inhibition of benzovindiflupyr and dimethachlon on carpogenic germination increased with increasing concentration (Fig. 4). Benzovindiflupyr at a concentration of $10 \mu \mathrm{g} / \mathrm{ml}$ showed the highest inhibitory effect on carpogenic germination; thus, inhibition decreased over time. In addition, the inhibition level of benzovindiflupyr on the carpogenic germination of sclerotia was significantly higher than that of dimethachlon after incubation for 50 days $(p=0.04)$ (Table 3$)$.

Systemic translocation of benzovindiflupyr in eggplant leaves. For eggplant at the five- or six-leaf stage, the efficacy of benzovindiflupyr at $100 \mu \mathrm{g} / \mathrm{ml}$ was 71.3 and $80.5 \%$ for transverse activity and cross-layer activity, respectively, which was higher than that in the acropetal and basipetal treatments (43.6 and $44.7 \%$, respectively). This result indicates that the translocation of benzovindiflupyr in leaves was better than that in stems. Overall, benzovindiflupyr showed better systemic translocation performance than dimethachlon, except for cross-layer activity $(P<0.01)$ (Fig. 5).

Table 1. Baseline sensitivity to benzovindiflupyr of Sclerotinia sclerotiorum isolates obtained from six crops

\begin{tabular}{lccc}
\hline & & \multicolumn{2}{c}{$\mathbf{E C}_{\mathbf{5 0}}(\boldsymbol{\mu g} / \mathbf{m l})^{\mathbf{z}}$} \\
\cline { 3 - 4 } Crop & Number & Range & Mean \\
\hline Eggplant & 34 & $0.0059-0.0563$ & $0.0269 \pm 0.0027 \mathrm{a}$ \\
Cucumber & 27 & $0.0033-0.0569$ & $0.0248 \pm 0.0024 \mathrm{a}$ \\
Tomato & 29 & $0.0048-0.0594$ & $0.0265 \pm 0.0026 \mathrm{a}$ \\
Pepper & 35 & $0.0041-0.0681$ & $0.0399 \pm 0.0181 \mathrm{a}$ \\
Pumpkin & 32 & $0.0033-0.0390$ & $0.0241 \pm 0.0012 \mathrm{a}$ \\
Kidney bean & 25 & $0.0145-0.0713$ & $0.0372 \pm 0.0034 \mathrm{a}$ \\
\hline
\end{tabular}

${ }^{\mathrm{z}} \mathrm{EC}_{50}$ values are the effective concentrations of fungicide that inhibited mycelium growth on a potato dextrose agar plate by $50 \%$. Mean values ( \pm standard errors) followed by different letters in the same column indicate that the difference was significant according to Bonferroni correction $(\alpha=0.05)$.
Greenhouse trials. In the two greenhouse experiments during 2017, the overall infection level was severe in the nontreated control. Nonetheless, all fungicide treatments significantly decreased the disease incidence (ranging from 8.72 to $16.92 \%$ in greenhouse 1 and 7.69 to $17.44 \%$ in greenhouse $2 ; P<0.01$ ) compared with the nontreated control $(28.72 \%$ in greenhouse 1 and $35.64 \%$ in greenhouse 2) (Fig. 6). In the two greenhouse trials, the disease incidence and severity decreased gradually as the benzovindiflupyr dose increased from 100 to $200 \mathrm{~g}$ a.i. ha ${ }^{-1}$. Eggplant treated with the highest dose of benzovindiflupyr had the lowest disease severity, and this treatment showed the lowest disease incidence $(8.72 \%$ in greenhouse 1 and $7.69 \%$ in greenhouse $2 ; P=0.01$ ). Benzovindiflupyr applied at 200 a.i. ha ${ }^{-1}$ also clearly reduced the disease severity (Table 4).

\section{Discussion}

When a novel fungicide is coming to market, knowledge of its antifungal activity and efficacy against different fungi is necessary not only to determine the antifungal spectrum but also to provide information for developing reasonable plant disease management strategies. Benzovindiflupyr, a new-generation SDHI fungicide from FRAC Group 7, shows very high potency on rusts, various leaf spots, apple scab, and powdery mildew and is being developed worldwide for use on wheat, cucurbits, peanut, potato, soybean, and other crops (Ishii et al. 2016). At present, few studies have investigated the efficacy of benzovindiflupyr against $S$. sclerotiorum. Therefore, this study is the first report of a potential assessment of benzovindiflupyr against $S$. sclerotiorum based on the growth stages of the fungus and properties of the fungicide and will provide useful information for disease management in the future.

To the best of our knowledge, single-site benzovindiflupyr, with a highly specific mode of action characteristic of SDHI fungicides, is especially prone to developing resistance. Currently, resistance to some SDHI fungicides such as carboxin, flutolanil, and boscalid has been documented in field populations of plant fungal pathogens after their registration (Avenot et al. 2008; Broomfield and Hargreaves 1992; Hu et al. 2016; Ito 2004). Before a new fungicide is introduced to the commercial market, the establishment of a sensitivity baseline is important for providing a reference value for understanding the risk of fungicide resistance development and for

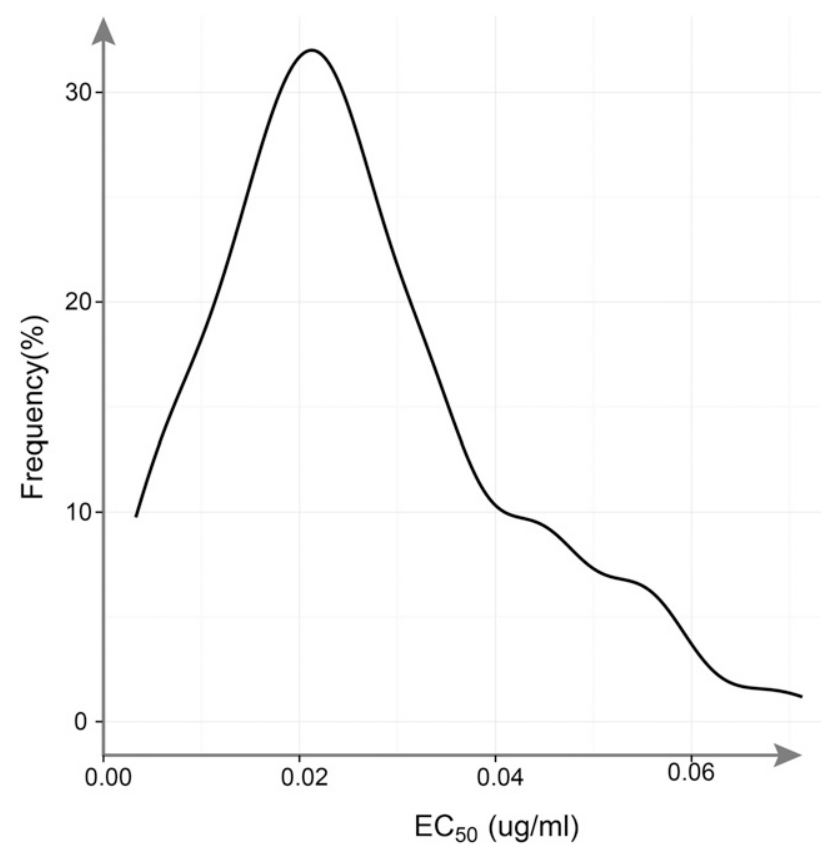

Fig. 2. Frequency distribution of $50 \%$ effective concentration $\left(\mathrm{EC}_{50}\right)$ values for benzovindiflupyr against 181 Sclerotinia sclerotiorum isolates collected from six crops in Shandong Province, China. 
monitoring population shifts toward resistance (Russell 2004; Villani et al. 2016). The results of the sensitivity bioassay showed that benzovindiflupyr markedly inhibited the mycelial growth of $S$. sclerotiorum. Furthermore, the unimodal curve of the frequency distribution of $\mathrm{EC}_{50}$ values and the narrow variation ranges indicated that the mean $\mathrm{EC}_{50}$ values of $0.0260 \mu \mathrm{g} / \mathrm{ml}$ can be used as a sensitivity baseline to monitor benzovindiflupyr resistance in the future.

Serving as the principal survival structures of S. sclerotiorum, sclerotia play a major role in the pathogen's life cycle (Abawi and Grogan 1979; Dai et al. 2006). The presence of sclerotia make this
A Control $\quad 0.2 \mu \mathrm{g} / \mathrm{ml} \quad 0.4 \mu \mathrm{g} / \mathrm{ml} \quad 0.8 \mu \mathrm{g} / \mathrm{ml}$

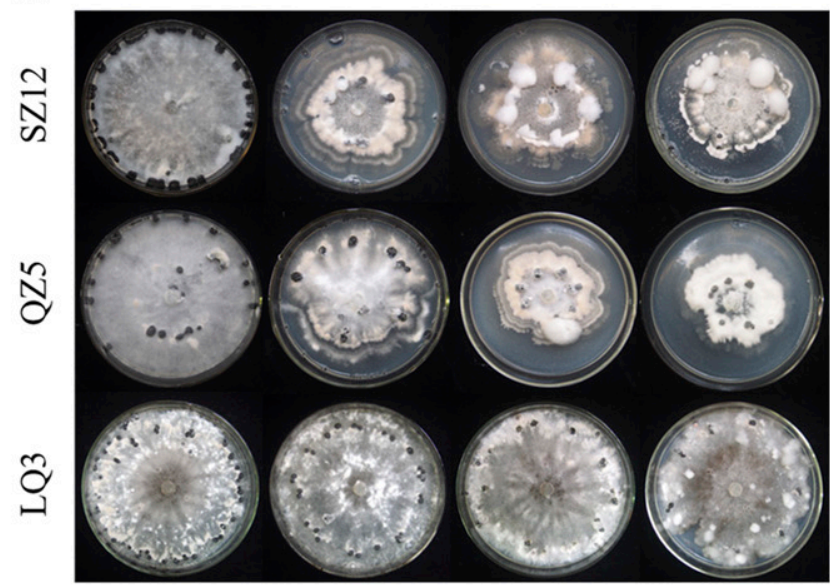

C

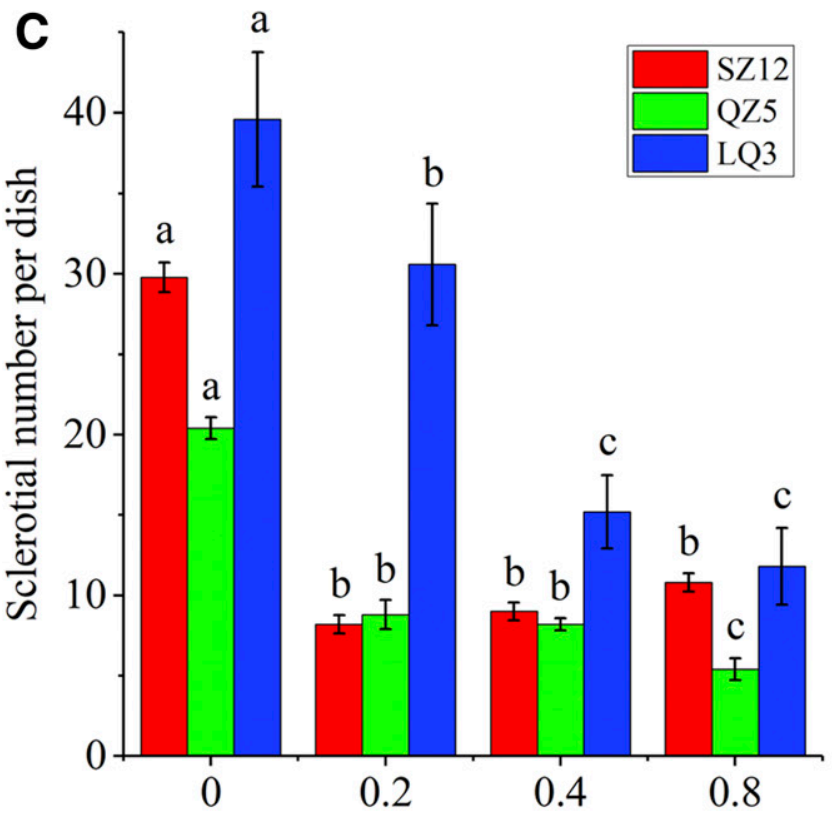

Concentration $(\mu \mathrm{g} / \mathrm{ml})$

\section{B $\quad$ Control $\quad 0.2 \mu \mathrm{g} / \mathrm{ml} \quad 0.4 \mu \mathrm{g} / \mathrm{ml} \quad 0.8 \mu \mathrm{g} / \mathrm{ml}$}
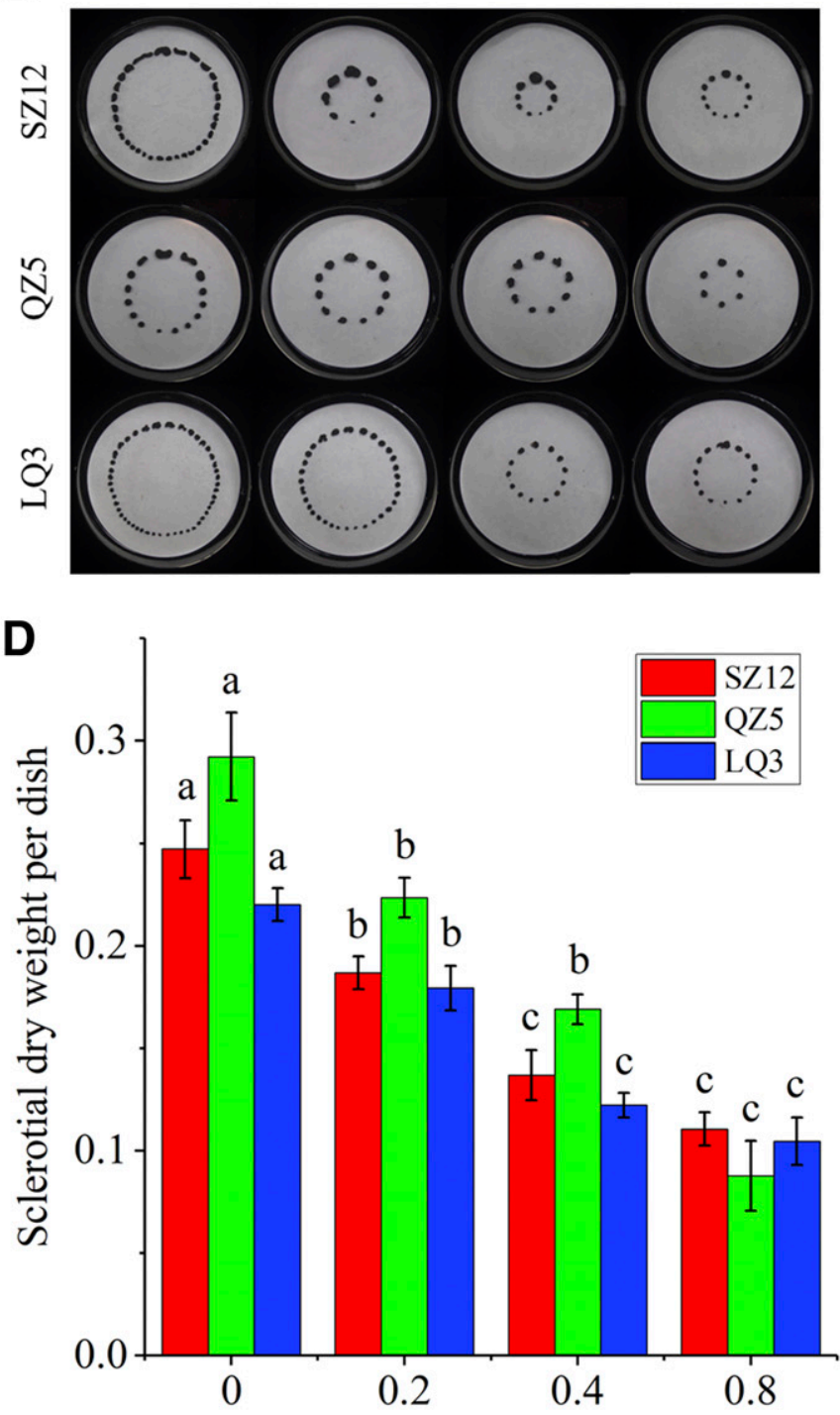

Concentration $(\mu \mathrm{g} / \mathrm{ml})$

Fig. 3. Effect of benzovindiflupyr on sclerotial production of Sclerotinia sclerotiorum. A, Growth phenotype in vitro. B, Sclerotial morphology. All the sclerotia in each dish were from A. C, Dry weight of sclerotia on each plate. D, Number of sclerotia on each plate. The error bar indicates the standard error. Different lowercase letters for each isolate indicate that the difference was significant after Bonferroni correction $(\alpha=0.05)$.

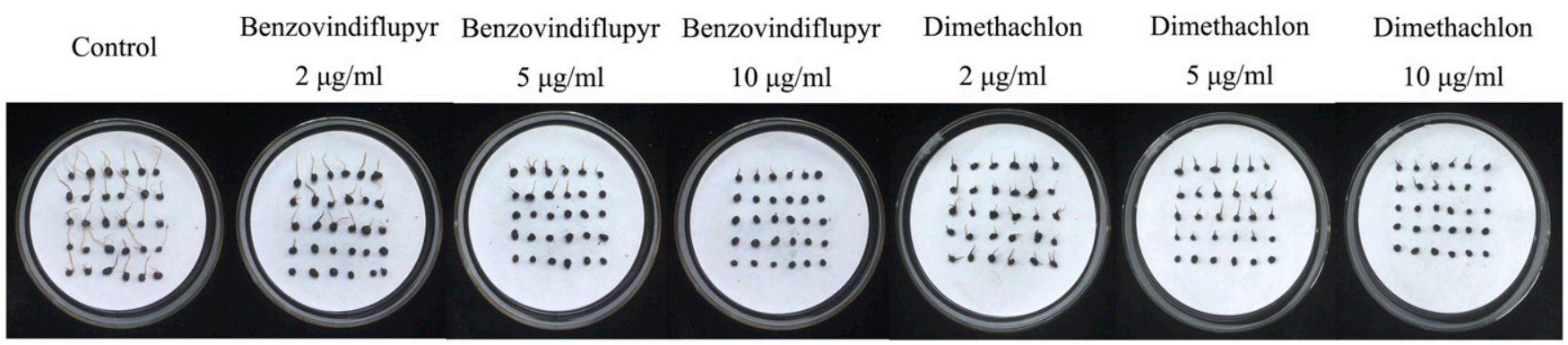

Fig. 4. Effects of benzovindiflupyr and dimethachlon on the carpogenic germination of sclerotia of Sclerotinia sclerotiorum. 
pathogen difficult to control for several reasons. (i) Sclerotia can remain viable for up to 8 years under stressful conditions, such as low moisture, temperature extremes, and the application of fungicides (Ben-Yephet et al. 1993; Li et al. 2012; Patterson and Grogan 1985). (ii) When conditions become favorable, sclerotia that germinate carpogenically produce apothecia and release ascospores, which could disseminate over a few kilometers and result in large-scale outbreaks of Sclerotinia stem rot. (Abawi and Grogan 1979; Clarkson et al. 2007; Newton and Sequeira 1972). (iii) Sclerotia can germinate myceliogenically to form hyphae, which can also directly infect the ground-level tissues of susceptible plants (Goussous et al. 2013; $\mathrm{Xu}$ et al. 2015). Therefore, inhibition of sclerotial vitality, sclerotial production, or mycelial infection and subsequent colonization is key to controlling S. sclerotiorum. Our results show that sclerotia were smaller at high fungicide concentrations, which indicates that benzovindiflupyr can inhibit sclerotial vitality; small sclerotia are less likely than large sclerotia to carpogenically germinate (Dillard et al. 1995). In addition, sclerotial production was suppressed after treatment with benzovindiflupyr at a concentration of $0.8 \mu \mathrm{g} / \mathrm{ml}$, which suggests that this fungicide may be able to minimize future disease epidemics by interfering with this phase of the S. sclerotiorum infection cycle. We also determined that benzovindiflupyr has effective inhibitory activity on the myceliogenic germination of sclerotia, which indicates that the fungicide can block mycelial growth of $S$. sclerotiorum in the field. The concentration that completely inhibited myceliogenic germination was apparently higher than that required to completely inhibit hyphal growth, which can be explained by sclerotia having a higher tolerance than hyphae to fungicides. At lower concentrations, the inhibition of benzovindiflupyr on the myceliogenic germination of sclerotia decreased over time. This effect may occur because the chemicals were degraded over time or because the response time of sclerotial germination was different (Goussous et al. 2013). In addition, we found that benzovindiflupyr was highly effective in inhibiting the carpogenic germination of

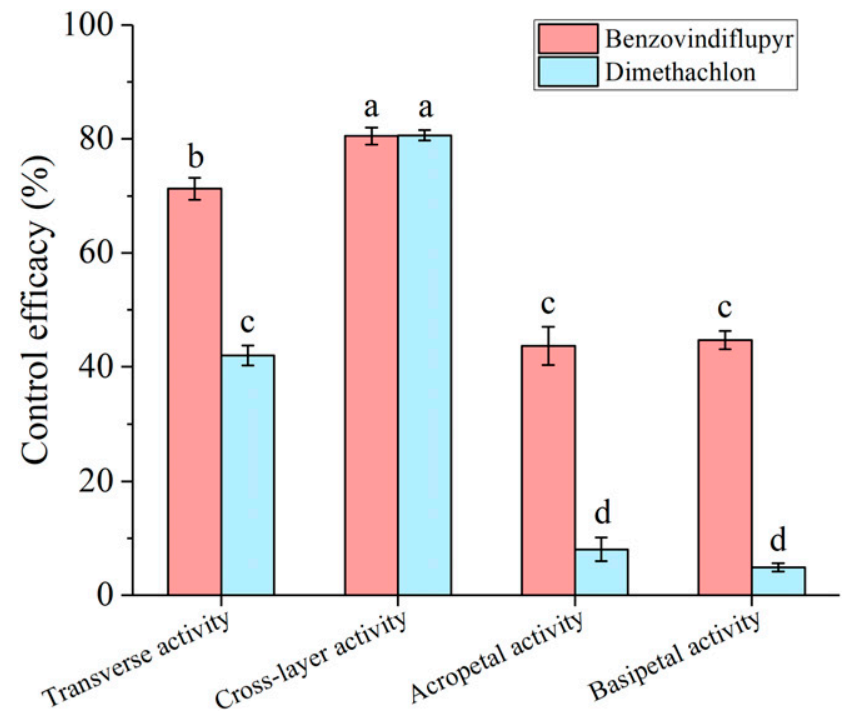

Fig. 5. Systemic translocation of benzovindiflupyr and dimethachlon at $100 \mu \mathrm{g} / \mathrm{ml}$ in eggplant leaves.

Table 2. Effect of benzovindiflupyr and dimethachlon on myceliogenic germination of sclerotia of Sclerotinia sclerotiorum ${ }^{\mathrm{y}}$

\begin{tabular}{|c|c|c|c|c|c|c|}
\hline \multirow[b]{3}{*}{ Fungicide $(\mu \mathrm{g} / \mathrm{ml})$} & \multicolumn{6}{|c|}{ Inhibition (\%) of myceliogenic germination of sclerotia ${ }^{z}$} \\
\hline & \multicolumn{3}{|c|}{ Isolate of SZ12 } & \multicolumn{3}{|c|}{ Isolate of QZ5 } \\
\hline & 3 days & 4 days & 5 days & 3 days & 4 days & 5 days \\
\hline \multicolumn{7}{|l|}{ Benzovindiflupyr } \\
\hline 0.5 & $72.3 \pm 3.2 \mathrm{~d}$ & $34.3 \pm 3.0 \mathrm{f}$ & $12.7 \pm 1.5 \mathrm{de}$ & $85.0 \pm 2.3 \mathrm{c}$ & $74.7 \pm 2.3 \mathrm{bc}$ & $35.3 \pm 3.9 \mathrm{~d}$ \\
\hline 1 & $75.7 \pm 4.5 \mathrm{~cd}$ & $33.3 \pm 6.9 \mathrm{f}$ & $19.3 \pm 5.4$ cde & $98.7 \pm 1.3 \mathrm{ab}$ & $86.7 \pm 2.0 \mathrm{bc}$ & $46.7 \pm 3.8 \mathrm{~cd}$ \\
\hline 2 & $84.3 \pm 2.9 \mathrm{bc}$ & $60.0 \pm 1.7 \mathrm{de}$ & $56.7 \pm 3.8 b$ & $100 \mathrm{a}$ & $85.3 \pm 3.9 \mathrm{~b}$ & $76.7 \pm 3.8 \mathrm{~b}$ \\
\hline 4 & $89.3 \pm 0.3 b$ & $81.7 \pm 1.7 \mathrm{bc}$ & $70.0 \pm 1.7 \mathrm{~b}$ & $100 \mathrm{a}$ & $100 \mathrm{a}$ & $95.7 \pm 3.0 \mathrm{a}$ \\
\hline 8 & $100 \mathrm{a}$ & $100 \mathrm{a}$ & $100 \mathrm{a}$ & $100 \mathrm{a}$ & $100 \mathrm{a}$ & $100 \mathrm{a}$ \\
\hline \multicolumn{7}{|l|}{ Dimethachlon } \\
\hline 0.5 & $72.0 \pm 4.5 \mathrm{~d}$ & $34.7 \pm 2.9 \mathrm{f}$ & $9.0 \pm 2 \mathrm{e}$ & $91.7 \pm 4.3 b c$ & $70.0 \pm 5.1 \mathrm{c}$ & $42.3 \pm 3.9 \mathrm{~cd}$ \\
\hline 1 & $78.7 \pm 1.9 \mathrm{~cd}$ & $55.0 \pm 2.9 \mathrm{e}$ & $24.0 \pm 1.5 \mathrm{~cd}$ & $99.0 \pm 1.0 \mathrm{ab}$ & $87.7 \pm 6.2 \mathrm{bc}$ & $59.0 \pm 4.9 \mathrm{bcd}$ \\
\hline 2 & $90.7 \pm 1.3 b$ & $73.0 \pm 2.1 \mathrm{~cd}$ & $33.3 \pm 2.0 \mathrm{c}$ & $100 \mathrm{a}$ & $86.0 \pm 3.2 \mathrm{~b}$ & $64.3 \pm 7.2 b c$ \\
\hline 4 & $100 \mathrm{a}$ & $85.3 \pm 2.9 \mathrm{~b}$ & $62.7 \pm 7.2 \mathrm{~b}$ & $100 \mathrm{a}$ & $97.7 \pm 2.3 \mathrm{a}$ & $96.7 \pm 2.0 \mathrm{a}$ \\
\hline 8 & $100 \mathrm{a}$ & $100 \mathrm{a}$ & $100 \mathrm{a}$ & $100 \mathrm{a}$ & $100 \mathrm{a}$ & $100 \mathrm{a}$ \\
\hline
\end{tabular}

y Percentage of myceliogenic germination inhibition of two isolates was examined after incubation for 3, 4, and 5 days. Inhibitions were calculated relative to an untreated control.

${ }^{\mathrm{z}}$ Mean values ( \pm standard errors) followed by different letters in the same column indicate that the difference was significant according to Bonferroni correction $(\alpha=0.05)$.

Table 3. Effect of benzovindiflupyr and dimethachlon on carpogenic germination of sclerotia of Sclerotinia sclerotiorum

\begin{tabular}{|c|c|c|c|c|c|c|}
\hline \multirow[b]{3}{*}{ Fungicide $(\mu \mathrm{g} / \mathrm{ml})$} & \multicolumn{6}{|c|}{ Inhibition $(\%)$ of carpogenic germination of sclerotia ${ }^{z}$} \\
\hline & \multicolumn{3}{|c|}{ Isolate of SZ12 } & \multicolumn{3}{|c|}{ Isolate of QZ5 } \\
\hline & 30 days & 40 days & 50 days & 30 days & 40 days & 50 days \\
\hline \multicolumn{7}{|l|}{ Benzovindiflupyr } \\
\hline 2 & $52.2 \pm 6.8 \mathrm{~cd}$ & $37.9 \pm 3.1 \mathrm{c}$ & $25.8 \pm 3.7 \mathrm{c}$ & $45.9 \pm 4.0 \mathrm{bc}$ & $42.9 \pm 2.7 \mathrm{~d}$ & $31.7 \pm 2.2 \mathrm{~d}$ \\
\hline 5 & $80.3 \pm 4.9 \mathrm{~b}$ & $69.8 \pm 3.9 \mathrm{~b}$ & $62.5 \pm 2.5 \mathrm{~b}$ & $68.1 \pm 2.4 \mathrm{~b}$ & $59.7 \pm 1.8 \mathrm{c}$ & $51.7 \pm 1.7 \mathrm{c}$ \\
\hline 10 & $96.3 \pm 1.5 \mathrm{a}$ & $85.7 \pm 3.5 \mathrm{a}$ & $79.2 \pm 1.6 \mathrm{a}$ & $93.2 \pm 2.0 \mathrm{a}$ & $82.4 \pm 2.1 \mathrm{a}$ & $77.5 \pm 0.8 \mathrm{a}$ \\
\hline \multicolumn{7}{|l|}{ Dimethachlon } \\
\hline 2 & $33.6 \pm 3.2 \mathrm{~d}$ & $11.8 \pm 3.2 \mathrm{~d}$ & $0.0 \pm 0.0 \mathrm{~d}$ & $32.8 \pm 6.6 \mathrm{c}$ & $11.2 \pm 2.0 \mathrm{e}$ & $3.3 \pm 1.4 \mathrm{e}$ \\
\hline 5 & $68.5 \pm 4.0 \mathrm{bc}$ & $45.7 \pm 3.1 \mathrm{c}$ & $25.0 \pm 3.5 \mathrm{c}$ & $48.5 \pm 5.6 \mathrm{bc}$ & $37.8 \pm 2.7 \mathrm{~d}$ & $29.2 \pm 1.6 \mathrm{~d}$ \\
\hline 10 & $84.9 \pm 4.4 \mathrm{ab}$ & $77.9 \pm 4.6 \mathrm{ab}$ & $60.8 \pm 2.8 \mathrm{~b}$ & $87.8 \pm 4.5 \mathrm{a}$ & $70.7 \pm 2.1 \mathrm{~b}$ & $66.7 \pm 1.9 \mathrm{~b}$ \\
\hline
\end{tabular}

${ }^{\mathrm{z}}$ Mean values ( \pm standard errors) followed by different letters in the same column indicate that the difference was significant according to Bonferroni correction $(\alpha=0.05)$. 
sclerotia, indicating that this fungicide has the potential to reduce outbreaks of Sclerotinia stem rot caused by the ascospores of S. sclerotiorum. Conclusively, benzovindiflupyr demonstrated a high level of activity against the production and germination of sclerotia, suggesting that this fungicide is best used as a protective agent by foliar application to prevent the crops from the infection of S. sclerotiorum.

Under some circumstances, the initial infection caused by $S$. sclerotiorum occurs on the leaves of plants and then expands to the stem through the leaves (Saharan and Mehta 2008). Once the stems are infected, plants often die due to the disruption of water and nutrient transport through the stems (Lujan et al. 2016). Considering that fungicides are not evenly sprayed on the stems or leaves of plants because of limited pesticide application technology or leaf barriers, we can infer that fungicides with strong systemic translocation are likely to provide overall coverage, thereby obtaining excellent efficacy in controlling S. sclerotiorum. He et al. (2017) demonstrated that isopyrazam, which has a high level of systemic movement, has satisfactory efficacy in the control of cucumber powdery mildew, superior to that of triazoles and strobilurin fungicides. Our results demonstrated that benzovindiflupyr has outstanding transverse activity and cross-layer activity, which may provide broad protection for both surfaces of leaves. Meanwhile, we found that the acropetal and basipetal activity of benzovindiflupyr were superior to that of dimethachlon, which indicated that benzovindiflupyr can be absorbed and then transported to stems by foliar application, thereby protecting stems or leaf axils from infection. In brief, the results implied that the product with good translocation has the superiority over the widely used fungicide dimethachlon in the control of Sclerotinia stem rot.

The aforementioned analysis and verification via laboratory tests provide fundamental assessments of the potential of benzovindiflupyr in managing the disease. However, greenhouse trials under natural conditions were also conducted to provide further evidence of its practical efficacy in suppressing the disease. In this study, we found that benzovindiflupyr at $200 \mathrm{~g}$ a.i. ha $^{-1}$ provided the highest level of efficacy among the tested fungicides in controlling Sclerotinia stem rot, which means that the greenhouse efficacy results of benzovindiflupyr against $S$. sclerotiorum were consistent with the levels of inhibition observed in the laboratory experiments.

In conclusion, the SDHI fungicide benzovindiflupyr has satisfactory bioactivity and systemicity and favorable efficacy in controlling Sclerotinia stem rot, which suggests that this fungicide can be used as an important part of disease management strategies to minimize the severity of the disease. Additionally, further research should focus
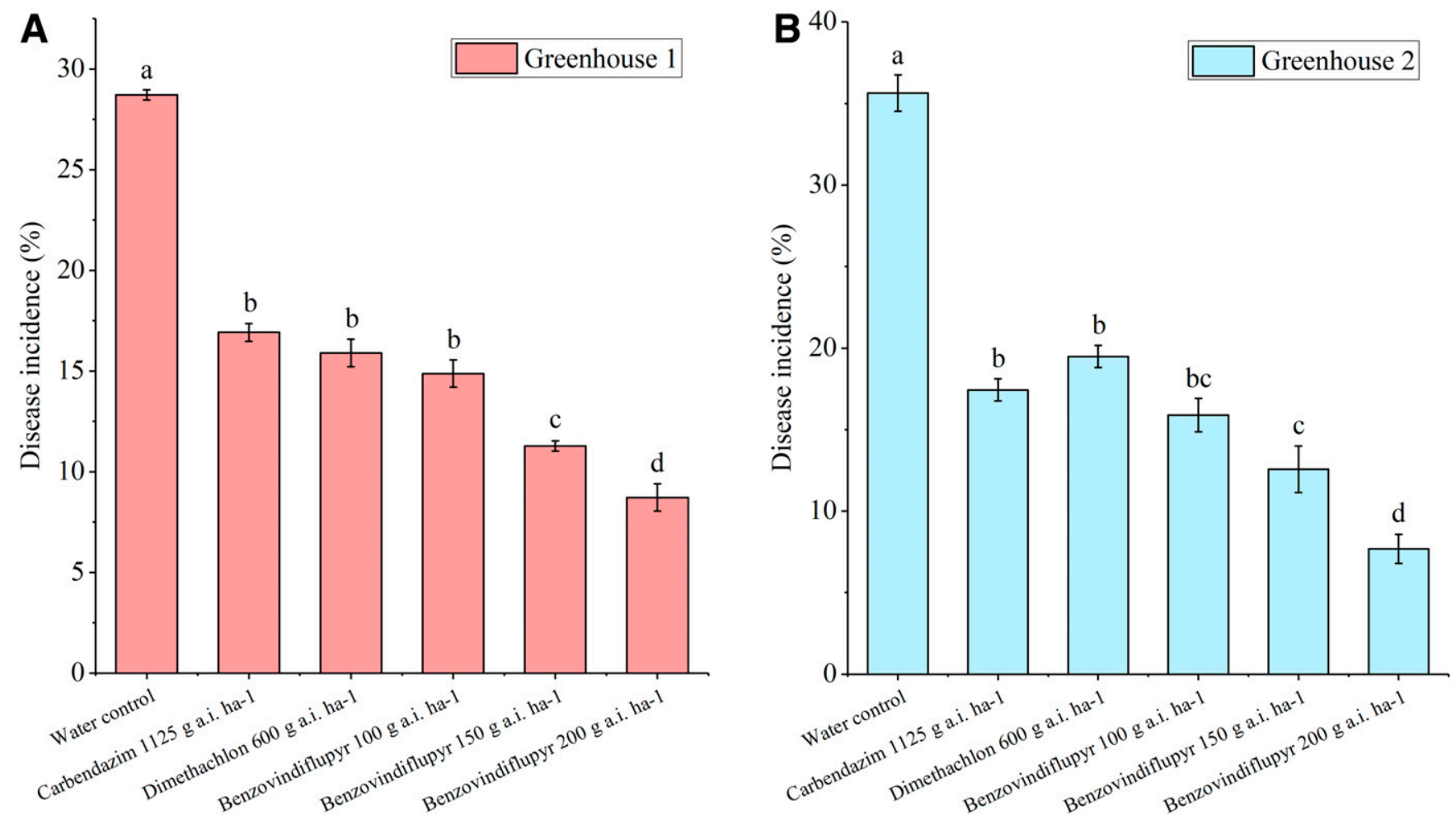

Fig. 6. Disease incidence of Sclerotinia stem rot in two greenhouse trials. Trial sites were located in A, Changle (greenhouse 1) and B, Tai'an (greenhouse 2). Values represent the mean of four replicates with standard errors. Bars with the same letters do not differ significantly from each other after Bonferroni correction $(\alpha=0.05)$.

Table 4. Mean disease rating (MDR), mean rank $\left(\bar{R}_{i}\right)$, and the relative treatment effects $\left(\hat{p}_{i}\right)$ along with $95 \%$ confidence intervals $(\mathrm{CI})$ for the severity of benzovindiflupyr in the control of Sclerotinia stem rot in the greenhouse ${ }^{y}$

\begin{tabular}{|c|c|c|c|c|c|c|c|c|c|}
\hline \multirow[b]{2}{*}{ Treatment $^{\mathrm{z}}$} & \multirow[b]{2}{*}{ Dose (g a.i. ha $\left.{ }^{-1}\right)$} & \multicolumn{4}{|c|}{ Greenhouse 1} & \multicolumn{4}{|c|}{ Greenhouse 2} \\
\hline & & MDR & $\overline{\boldsymbol{R}}_{i}$. & $\hat{p}_{i}$ & $95 \%$ CI for $\hat{p}_{i}$ & MDR & $\overline{\boldsymbol{R}}_{\boldsymbol{i}}$. & $\hat{p}_{i}$ & $95 \%$ CI for $\hat{p}_{i}$ \\
\hline Water control & $\ldots$ & 1.22 & 31.80 & 0.48 & $(0.42,0.56)$ & 1.33 & 35.60 & 0.54 & $(0.46,0.61)$ \\
\hline Carbendazim, 50\% WP & 1,125 & 0.51 & 15.25 & 0.52 & $(0.37,0.67)$ & 0.41 & 16.00 & 0.47 & $(0.33,0.60)$ \\
\hline Dimethachlon, $40 \%$ WP & 600 & 0.44 & 14.25 & 0.53 & $(0.49,0.56)$ & 0.34 & 15.00 & 0.47 & $(0.44,0.51)$ \\
\hline \multirow[t]{3}{*}{ Benzovindiflupyr, $100 \mathrm{~g}$ liter $^{-1} \mathrm{EC}$} & 100 & 0.35 & 12.25 & 0.37 & $(0.21,0.54)$ & 0.32 & 11.00 & 0.44 & $(0.14,0.52)$ \\
\hline & 150 & 0.20 & 8.67 & 0.31 & $(0.29,0.33)$ & 0.19 & 10.00 & 0.33 & $(0.14,0.48)$ \\
\hline & 200 & 0.14 & 9.00 & 0.21 & $(0.19,0.23)$ & 0.12 & 8.00 & 0.31 & $(0.14,0.48)$ \\
\hline
\end{tabular}

y Differences in the $\hat{p}_{i}$ values are used to compare treatments.

${ }^{\mathrm{z}} \mathrm{WP}=$ wettable powder and $\mathrm{EC}=$ emulsifiable concentrate. 
on the residue analysis of benzovindiflupyr in environmental and biological samples to identify the effects of the fungicide on nontarget species, aquatic organisms, or human beings, thereby obtaining a more comprehensive application potential assessment.

\section{Literature Cited}

Abawi, G. S., and Grogan, R. G. 1979. Epidemiology of diseases caused by Sclerotinia species. Phytopathology 69:899-904.

Allen, T. W., Bradley, C. A., Sisson, A. J., Byamukama, E., Chilvers, M. I., Coker, C. M., et al. 2017. Soybean yield loss estimates due to diseases in the United States and Ontario, Canada, from 2010 to 2014. Plant Health Prog. 18:19-27.

Avenot, H. F., Sellam, A., Karaoglanidis, G., and Michailides, T. J. 2008. Characterization of mutations in the iron-sulphur subunit of succinate dehydrogenase correlating with boscalid resistance in Alternaria alternata from California pistachio. Phytopathology 98:736-742.

Ben-Yephet, Y., Genizi, A., and Siti, E. 1993. Sclerotial survival and apothecial production by Sclerotinia sclerotiorum following outbreaks of lettuce drop. Phytopathology 83:509-513.

Boland, G. J., and Hall, R. 1994. Index of plant hosts of Sclerotinia sclerotiorum. Can. J. Plant Pathol. 16:93-108.

Bolton, D. M., Thomma, B. P., and Nelson, B. D. 2006. Sclerotinia sclerotiorum (lib.) de Bray: Biology and molecular traits of a cosmopolitan pathogen. Mol. Plant Pathol. 7:1-16.

Broomfield, P. L., and Hargreaves, J. A. 1992. A single amino-acid change in the iron-sulphur protein subunit of succinate dehydrogenase confers resistance to carboxin in Ustilago maydis. Curr. Genet. 22:117-121.

Clarkson, J. P., Phelps, K., Whipps, J. M., Young, C. S., Smith, J. A., and Watling, M. 2007. Forecasting Sclerotinia disease on lettuce: A predictive model for carpogenic germination of Sclerotinia sclerotiorum sclerotia. Phytopathology 97:621-631.

Dai, F. M., Xu, T., Wolf, G. A., and He, Z. H. 2006. Physiological and molecular features of the pathosystem Arabidopsis thaliana L.-Sclerotinia sclerotiorum Libert. J. Integr. Plant Biol. 48:44-52.

Dillard, H. R., Ludwig, J. W., and Hunter, J. E. 1995. Conditioning sclerotia of Sclerotinia sclerotiorum for carpogenic germination. Plant Dis. 79:411-415.

European Food Safety Authority. 2015. Conclusion on the peer review of the pesticide risk assessment of the active. EFSA J. 13:4043.

Goussous, S. J., Mas'ad, I. S., Abu El-Samen, F. M., and Tahhan, R. A. 2013. In vitro inhibitory effects of rosemary and sage extracts on mycelial growth and sclerotial formation and germination of Sclerotinia sclerotiorum. Arch. Phytopathol. Plant Prot. 46:890-902.

Griffith, G. W., Easton, G. L., Detheridge, A., Roderick, K., Edwards, A., Worgan, H. J., et al. 2007. Copper deficiency in potato dextrose agar causes reduced pigmentation in cultures of various fungi. FEMS Microbiol. Lett. 276:165-171.

He, L.-m., Cui, K.-d., Ma, D.-c., Shen, R.-p., Huang, X.-p., Jiang, J-g., Mu, W., and Liu, F. 2017. Activity, translocation and persistence of isopyrazam for controlling cucumber powdery mildew. Plant Dis. 101:1139-1144.

Hu, M., Fernández-Ortuño, D., and Schnabel, G. 2016. Monitoring resistance to SDHI fungicides in Botrytis cinerea from strawberry fields. Plant Dis. 100: 959-965.

Ishii, H., Zhen, F., Hu, M., Li, X., and Schnabel, G. 2016. Efficacy of SDHI fungicides including benzovindiflupyr against Colletotrichum species. Pest Manage. Sci. 72:1844-1853.

Ito, Y. 2004. Flutolanil and carboxin resistance in Coprinus cinereus conferred by a mutation in the cytochrome $b_{560}$ subunit of succinate dehydrogenase complex (Complex II). Mol. Genet. Genomics 272:328-335.

Jeanmart, S., Edmunds, A. J. F., Lamberth, C., and Pouliot, M. 2016. Synthetic approaches to the 2010-2014 new agrochemicals. Bioorg. Med. Chem. 24: $317-341$

Koenning, S. R., and Wrather, J. A. 2010. Suppression of soybean yield potential in the continental United States by plant diseases from 2006 to 2009. Plant Health Prog. 11. doi:10.1094/PHP-2010-1122-01-RS

Li, M., Liang, X., and Rollins, J. A. 2012. Sclerotinia sclerotiorum $\gamma$-glutamyl transpeptidase (Ss-Ggt1) is required for regulating glutathione accumulation and development of sclerotia and compound appressoria. Mol. Plant-Microbe Interact. 25:412-420.

Liang, H. J., Di, Y. L., Li, J. L., You, H., and Zhu, F. 2015. Baseline sensitivity of pyraclostrobin and toxicity of SHAM to Sclerotinia sclerotiorum. Plant Dis. 99:267-273

Lu, X. M., Zhu, Z. Q., Di, Y. L., and Zhu, F. X. 2015. Baseline sensitivity and toxic action of flusilazole to Sclerotinia sclerotiorum. Crop Prot. 78:92-98.

Lujan, M. P. A., Sanogo, S., Puppala, N., and Randall, J. 2016. Factors affecting mycelium pigmentation and pathogenicity of Sclerotinia sclerotiorum on Valencia peanut. Can. J. Plant Sci. 96:461-473.

McCreary, C. M., Depuydt, D., Vyn, R. J., and Gillard, C. L. 2016. Fungicide efficacy of dry bean white mold [Sclerotinia sclerotiorum, (lib.) de Bary, causal organism] and economic analysis at moderate to high disease pressure. Crop Prot. 82:75-81.

Newton, H. C., and Sequeira, L. 1972. Ascospores as the primary infective propagule of Sclerotinia sclerotiorum in Wisconsin. Plant Dis. Rep. 56 798-802.

Ojaghian, M. R., Chen, Y., Chen, S., Cui, Z. Q., Xie, G. L., and Zhang, J. 2014 Antifungal and enzymatic evaluation of plant crude extracts derived from cinnamon and rosemary against Sclerotinia carrot rot. Ann. Appl. Biol. 164: 415-429.

Patterson, C. L., and Grogan, R. G. 1985. Differences in epidemiology and control of lettuce drop caused by Sclerotinia minor and S. sclerotiorum. Plant Dis. 69:766-770.

Purdy, L. H. 1979. Sclerotinia sclerotiorum: History, diseases and symptomatology, host range, geographic distribution, and impact. Phytopathology 69:875-880

Ren, H. M., Zhao, Y. H., Fan, F., Wang, S. T., Zhang, Y., and Cao, K. Q. 2011 Research on biological activity and the uptake translocation of chrysophanol against Sphaerotheca fuliginea in cucumber. Chin. J. Pestic. Sci. 13:535-538.

Russell, P. E. 2004. Sensitivity baselines in fungicide resistance research and management. FRAC Monogr. No. 3. Crop Life International, Fungicide Resistance Action Committee (FRAC), Brussels, Belgium. http://www.frac info/docs/default-source/publications/monographs/monograph-3.pdf

Saharan, G. S., and Mehta, N. 2008. Sclerotinia Diseases of Crop Plants: Biology, Ecology and Disease Management. Springer Science \& Business Media.

Shah, D. A., and Madden, L. V. 2004. Nonparametric analysis of ordinal data in designed factorial experiments. Phytopathology 94:33-43.

Steadman, J. R. 1979. Control of plant diseases caused by Sclerotinia species. Phytopathology 69:904-907.

Thomulka, K. W., Abbas, C. G., Young, D. A., and Lange, J. H. 1996. Evaluating median effective concentrations of chemicals with bioluminescent bacteria. Bull. Environ. Contam. Toxicol. 56:446-452.

Tores, J. A., and Moreno, R. 1987. Lesion development factors following inoculation of Sclerotinia sclerotiorum, mycelium to eggplant, tomato and French bean. Phytoparasitica 15:325-333.

Villani, S. M., Ayer, K., and Cox, K. 2016. Molecular characterization of the $s d h B$ gene and baseline sensitivity to penthiopyrad, fluopyram, and benzovindiflupyr in Venturia inaequalis. Plant Dis. 100:1709-1716.

Wang, Y., Hou, Y. P., Chen, C. J., and Zhou, M. G. 2014. Detection of resistance in Sclerotinia sclerotiorum, to carbendazim and dimethachlon in Jiangsu Province of China. Australas. Plant Pathol. 43:307-312.

Wu, B. M., and Subbarao, K. V. 2008. Effects of soil temperature, moisture, and burial depths on carpogenic germination of Sclerotinia sclerotiorum and S. minor. Phytopathology 98:1144-1152.

Xu, C., Liang, X., Hou, Y. P., and Zhou, M. 2015. Effects of the novel fungicide benzothiostrobin on Sclerotinia sclerotiorum in the laboratory and on Sclerotinia stem rot in rape fields. Plant Dis. 99:969-975.

Yang, D., Bo, W., Wang, J., Yu, C., and Zhou, M. 2009. Activity and efficacy of Bacillus subtilis strain NJ-18 against rice sheath blight and Sclerotinia stem rot of rape. Biol. Control 51:61-65.

Zhou, F., Zhang, X. L., Li, J. L., and Zhu, F. X. 2014. Dimethachlon resistance in Sclerotinia sclerotiorum in China. Plant Dis. 98:1221-1226.

Zhu, Z. Q., Zhou, F., Li, J. L., Zhu, F. X., and Ma, H. J. 2016. Carbendazim resistance in field isolates of Sclerotinia sclerotiorum, in China and its management. Crop Prot. 81:115-121. 